\title{
Analisis Fenomenologi Terhadap Makna dan Realita
}

\author{
Moh. Nadhir Mu'ammar \\ UIN Sunan Gunung Djati Bandung \\ nahdir99@gmail.com
}

\begin{abstract}
:
Phenomenology is precisely this deepening of self consciousness, this restless search for what lies back of the objects in which we ordinarily and scientifically lose our attention, or as we now call it our intention. Phenomenology is not merely the theory that this is so, but the putting it into practice, the urge to explore its interminable vistas. As a discipline, it is distinct from but related to other keys in philosophy: such as ontology, epistemology, logics, and ethics. The discipline of phenomenology is defined by its domain of study, its methods, and its main results. This paper globally makes a try at exploring the history and varieties of phenomenology. Phenomenology has been practiced in various guises for centuries, but it came into its down in the early $20^{\text {th }}$ century in the works of Husserl, Heidegger, Merleau-Ponty and others. Phenomenological issues of intentionality, consciousness, and first-person perspective have been prominent in recent philosophy of mind.
\end{abstract}

Keywords: Philosophy, Phenomenology, Idealism, Realism, Transcendental.

\section{A. Pendahuluan}

Gerak mengikuti tuntutan-tuntutan pengambilan kesadaran budaya-budaya lain atas diri mereka sendiri dan keinginan untuk mengkaji kesadaran Eropa dengan suatu kesadaran netral, melahirkan "struktur dan perkembangan kesadaran Eropa". Tema ini mencari tempatnya dalam registrasi Akademi. Istilah "Eropa" terkadang digantikan oleh istilah "Barat". Yang pertama menunjuk kepada ranah logika (budaya), sedangkan yang kedua menunjuk kepada ranah material (peradaban). Dan dua manifestasi yang menonjol dari aktivitas kesadaran Eropa adalah sains dan filsafat. ${ }^{1}$ Istilah 'kesadaran' digunakan untuk menunjuk sumber produktif di luar budaya: yang mengarah pada produksi yang memuat keseluruhan karya. Kesadaran Eropa dijadikan sebuah fenomena untuk dikaji. Ia diamati baik oleh para filsuf ataupun peneliti, di dalam maupun di luar budaya Eropa. Jika filsuf berusaha mencatat karakter krisis sains-sains Eropa, menskematisasi kemunduran Barat atau mengumandangkan nihilisme dan destruksi semua nilai,

\footnotetext{
${ }^{1}$ Hasan Hanafī, Tafsir fenomenologi: Bag. 1 / Hasan Hanafi; penerjemah: Yudian Wahyudi ; kata pengantar: Yudian W. Asmin (Pesantren Pasca Sarjana Bismillah Press, 2001), 1.
} 
maka penulis mencoba memilih suatu periode kesadaran Eropa sambil menganalisa krisisnya.

Fenomenologi kesadaran Eropa memiliki preseden dalam filsafat sejarah. Setelah Renaissans, filsafat lahir untuk menentukan hubungan antara filsafat cahaya dalam hubungannya dengan filsafat-filsafat terdahulu, khususnya filsafatfilsafat skolastik. Setiap zaman memiliki semangatnya sendiri. Dalam Zaman Modern, sebuah filsafat sejarah lahir untuk menentukan perkembangan sistemsistem filsafat. Fenomena kesadaran Eropa merupakan suatu produk budaya yang membawa nama yang sama. Basis filsafat kontinental yang diletakkan oleh Hegel dan Nietzsche abad ke-19 bercabang pada abad ke-20 menjadi beberapa bidang kajian yang dikaitkan dengan sejumlah pemikir kunci: fenomenologi, Edmund Husserl (1859-1938), Martin Heidegger (1889-1976) dan Jean-Paul Sartre (19051980); hermeneutika, Hans Georg Gadamer (1900) dan Paul Ricoeur (1913); poststrukturalisme, Michel Foucault (1926-1984), Roland Barthes (1915-1980), JeanFrançois Lyotard (1924) dan Jacques Derrida (1930 -2004), dan teori kritis, Jürgen Habermas (1929), Theodor Adorno (1903-1969), Max Horkheimer (18951971) dan Louis Althusser (1918-1990). ${ }^{2}$ Secara sederhana, tujuan fenomenologi adalah intensifikasi dan memperdalam kepastian, lalu menyebarkannya di seluruh struktur intensional yang membentuk dunia manusia. Pengetahuan ini tidak hanya eksistensial. Ia juga pasti, meski tak menentukan, dan terbuka atas pelbagai perspektif penafsiran lebih lanjut. ${ }^{3}$

Fenomenologi --di samping filsafat kritis dan filsafat analitis-- merupakan salah satu aliran utama filsafat abad ke-20. ${ }^{4}$ Para fenomenolog hari ini mengklaim telah memberikan pencerahan mengenai tindakan yang ada di dunia. Penulis bersedia untuk menerima klaim tersebut, paling tidak untuk beberapa alasan. Tapi mereka jarang atau hampir tidak mengungkapkan bagaimana eksistensi itu diketahui.

\footnotetext{
${ }^{2}$ Alun Munslow, The Routledge Companion to Historical Studies (Taylor \& Francis, 2006), 6869 .

${ }^{3}$ John Wild, Contemporary Phenomenology and the Problem of Existence (U of Buffalo/N.V. Erven P. Noordhoff, n.d.), 177.

${ }^{4}$ Francisco Budi Hardiman, Kritik ideologi: pertautan pengetahuan dan kepentingan (Penerbit Kanisius, 1993), 10.
} 
Heidegger mengungkapkan, misalnya, dalam Sein und Zeit, mengenai kemungkinan untuk menafsirkan eksistensi manusia dari sudut pandang wujud itu sendiri dimana seseorang telah memahami secara kabur dan pra-tematis. Agaknya inilah yang dia lakukan. Namun apakah ia hanya memandang kesadarannya sendiri? Jika demikian, apa dasar bagi pelbagai pernyataan umum yang memenuhi buku? Apakah pengetahuan ini pasti dan dekat? Menarikkah atau tidak? Pertanyaan-pertanyaan ini tidak dihadapi atau terjawab secara jelas. ${ }^{5}$ Bagaimana kita mengetahui eksistensi? Tentu saja, persoalan ini sangat mendasar dan bertalian dengan banyak isu-isu lain. Namun demikian, dalam waktu yang tersedia, Penulis berharap dapat membuat sugesti-sugesti sebagai jawaban yang lahir dari fenomenologi itu sendiri, yang layak didiskusikan.

Penelitian ini berjenis kualitatif, yaitu dengan penelitian kepustakaan (library research), yaitu dengan menelusuri data pustaka yang ada dalam buku serta melengkapinya dengan pustaka lain yang berhubungan dengan kajian dimaksud. Penelitian ini dilakukan dengan membaca, menelaah, dan menganalisis content buku dan didukung berbagai literatur yang berhubungan dengannnya. Penelitian ini bersifat deskriptif-analitik, yaitu penelitian yang berfungsi untuk menyelesaikan masalah melalui pengumpulan, penyusunan, dan proses analisa mendalam terhadap data yang ada untuk kemudian dijelaskan dan selanjutnya diberi penilaian. ${ }^{6}$

\section{B. Kajian Pustaka}

Salah satu perubahan terbesar dalam perspektif manusia tentang dirinya sendiri berlangsung di Eropa, pada abad 13 dan 17 M. Sebab, di abad pertengahan, manusia memandang segala hal dari sudut pandang 'ketuhanan'; kaitannya dengan Tuhan yang menciptakan, mengarahkan, mempertahankan, serta penyelamat manusia dan seluruh alam raya. Munculnya modernitas mengubah paradigma berpikir ini, bahkan peralihan tersebut -pada satu keadaan-- bersifat dekonstruktif; reformasi abad-16 yang menolak banyak klaim Gereja, serta dasar-

${ }^{5}$ Wild, Contemporary Phenomenology and the Problem of Existence, 167.

${ }^{6}$ Rianto Adi, Metodologi penelitian sosial dan hukum (Granit, 2004), 128. 
dasar ateism yang dirumuskan oleh filsuf era itu. Hal ini yang mengantarkan peradaban Eropa menuju masa pencerahan.

Titik poin yang hendak disinggung adalah, di dalam era kebangkitan terdapat satu kunci pokok modernitas: kesadaran akan 'subjektivitas'. Subjektif di sini bukan sebagai lawan dari objektif, melainkan dari kata subjek (aku) sebagai yang menghendaki, bertindak serta mengerti. Subjektivitas adalah unsur hakiki dalam paradigma antroposentris. ${ }^{7}$ Dengan demikian, pada abad 15 dan $16 \mathrm{M}$, selain masa revitalisasi agama (al-ishlah al-dini) dan masa kebangkitan Eropa ('asr al-nahdah), pada saat itu pula muncul penekanan segala hal pada sudut pandang manusia; antroposentris (al-ittijah al-insani).

Titik sentral dalam peradaban Eropa --sebagaimana dikatakan Husserl-adalah ego Cogito Cartesian. Dari ego Cartesian muncul dua aliran yang bertentangan. Pertama, rasionalisme, tokohnya adalah Cartesian pertama, Spinoza. Kedua, empirisme, dengan tokohnya David Hume (w. 1776), John Stewart, dan John Locke (w. 1704). Pertentangan ini berlanjut pada perseteruan dua aliran besar filsafat Eropa; idealis dan realis. ${ }^{8}$

Edmund Husserl (w. 1938) hadir 4 kurun setelah muculnya kesadaran Eropa pada abad ke 19, dan disebut-sebut sukses menyatukan kecenderungan idealis dan realis. Husserl berupaya membongkar filsafat Barat, dengan menghancurkan ketertutupan kesadaran. Karena "kesadaran" sesuai kodratnya mengarah ke realitas. Kemudian Husserl menciptakan pendekatan filsafat yang menganalisa "kesadaran" dan objek-objeknya secara sistemik dan berdasarkan pengalaman. Pendekatan ini yang kemudian dinamakan "fenomenologi".

Semula, pada abad ke-18, "fenomenologi" berarti teori mengenai penampakan fundamental bagi pengetahuan empiris, khususnya penampakanpenampakan sensor. Term itu diperkenalkan oleh Johann Heinrich Lambert, seorang pengikut Christian Wolff, pada tahun 1764. Kemudian, Immanuel Kant menggunakan istilah tersebut dalam sejumlah tulisannya, seperti yang dilakukan Johan Gottlieb Fichte. Pada 1807, G. W. F. Hegel menulis sebuah buku yang

\footnotetext{
${ }^{7}$ Franz Magnis-Suseno, Menalar Tuhan (Kanisius, 2006), 50.

${ }^{8}$ N. Driyarkara:, Percikan Filsafat, 2013, 120.

${ }^{9}$ Munslow, The Routledge Companion to Historical Studies, 69.
} 
berjudul Phänomenologie des Geistes (Phenomenology of Spirit). Franz Brentano (1889) menggunakan term fenomenologi untuk menggolongkan apa yang disebutnya "psikologi deskriptif". 10

Dalam Phänomenologie des Geistes (1807), Hegel menunjukkan bahwa kesadaran kritis atau subjek pengetahuan itu tidak serba-jadi, melainkan berada dalam proses pembentukan (bildungsprozess). Dengan demikian, kesadaran kritis mesti dapat ditelusuri asal usulnya. Berbeda dari Kant, dalam pandangannya, pengetahuan kritis justru dihasilkan oleh "kesadaran yang telah menyadari asalusulnya dan proses pembentukan dirinya". ${ }^{11}$

Kritik pengetahuan Hegel tidak dilakukan dengan pendekatan transendental, melainkan fenomenologis. Fenomenologi dalam arti ini adalah pengalaman kesadaran atau pengalaman refleksi. Berbeda dari epistemologi yang mengklaim diri bebas dari pengandaian, pengalaman refleksi mengakui ketergantungannya pada sesuatu yang mendahuluinya yang kita jadikan titik tolak. ${ }^{12}$ Menurutnya, titik tolak kegiatan refleksi adalah rasa kepastian (sense of certainty) terhadap objek yang langsung kita sadari secara inderawi. Rasa kepastian ini merupakan kesadaran kita sehari-hari terhadap objek sekeliling yang kita alami secara langsung. Jadi, kesadaran ini bersifat elementer. Bertolak dari sini, terjadilah refleksi kesadaran yang lebih tinggi dan kompleks. Dalam karyanya, Hegel menggambarkan bagaimana proses pembentukan-diri kesadaran -dari bentuk kesadaran elementer itu-- ke bentuk kesadaran sosial dalam sejarah umat manusia: hukum dan moral, dan berakhir pada pengetahuan absolut. ${ }^{13}$

Fenomenologi sampai pada bentuknya oleh -atau pada era- Husserl, selayaknya epistemologi oleh Descartes, dan ontologi atau metafisika oleh Aristoteles yang bersandar pada Plato. Ketika Descartes, Hume dan Kant menggolongkan keadaan-keadaan persepsi, pemikiran, dan imaginasi, mereka telah sedang mempraktekkan fenomenologi. Demikian pula ketika para filsuf akal

\footnotetext{
${ }^{10}$ Tajul Arifin, Western Philosophy (Bandung: Postgraduate Program The Sunan Gunung Djati State Islamic University, 2012), 218.

${ }^{11}$ Hardiman, Kritik ideologi, 126-127.

12 Ibid., 129.

${ }^{13}$ Karl Ameriks, The Cambridge Companion to German Idealism (Cambridge University Press, 2000).
} 
analitis mutakhir menunjukkan isu-isu perihal kesadaran dan intensionalitas. Tetapi, disiplin fenomenologi, yang berurat-akar selama berabad-abad, berbunga pada masa Husserl.

Fenomenologi, secara etimologis, adalah terusan dari fenomenon dan logos. Akar kata yang termuat dalam istilah fenomenon sama dengan: fantasi, fantom, fosfor, foto, yang artinya: sinar, cahaya. Dari akar kata itu dibentuk kata kerja, yang antara lain berati: nampak, terlihat karena bercahaya, bersinar. Dari sini tersalur kata fenomenon: sesuatu yang tampak, yang terlihat karena bercahaya. Dalam bahasa kita: gejala. ${ }^{14}$

Jadi fenomenologi berarti uraian atau percakapan tentang fenomena atau sesuatu yang sedang menampakkan diri. Menurut cara berpikir dan berbicara filsafat dewasa ini dapat juga dikatakan sebagai 'percakapan dengan fenomenon, atau sesuatu yang sedang menggejala'. Dengan keterangan ini mulai nampaklah tendensi yang terdalam dari aliran fenomenologi, yang sebetulnya merupakan cita-cita dan dan jiwa dari semua filsafat yakni pengertian yang benar, sedalamdalamnya. Filsuf itu haus akan pengertian yang benar. Pengertian yang benar ialah pengertian yang menangkap realitas, dan menangkap menurut tuntutan realitas itu sendiri.

Seiring dengan gerak dinamika dan dialektikanya, cukup banyak definisi tentang fenomenologi. Di antaranya, definisi yang menyatakan fenomenologi "as the reflective, first-person science of consciousness --in contrast with physics taken as the hypothetico-deductive, third-person science of nature at its most basic level". ${ }^{15}$ Husserl sendiri mendefinisikan fenomenologi sebagai science of pure phenomena. ${ }^{16}$ The Oxford English Dictionary merepresentasikan definisi fenomenologi: (1) Ilmu mengenai fenomena yang berbeda dari wujud (ontologi), (2) Cabang ilmu yang mendeskripsikan dan mengklasifikasikan fenomenanya. Fenomenologi, diderivasi dari bahasa Yunani phainomenon: penampakan. Dalam

\footnotetext{
${ }^{14}$ N. Driyarkara:, Percikan Filsafat, 119.

${ }^{15}$ David Hyder and Hans-Jörg Rheinberger, Science and the Life-World: Essays on Husserl's Crisis of European Sciences (Stanford University Press, 2009), 1.

${ }^{16}$ Edmund Husserl, The Idea of Phenomenology: A Translation of Die Idee Der Phänomenologie Husserliana II (Springer Science \& Business Media, 2013), 2.
} 
filsafat, ia digunakan dalam pengertian pertama, di tengah-tengah perdebatan teori dan metodologi. Dalam fisika dan filsafat sains, ia dipergunakan pengertian kedua, walaupun hanya kadang-kadang.

Fenomenologi biasanya dipahami dengan dua cara: sebagai kajian disipliner dalam filsafat, atau sebagai sebuah pergerakan dalam sejarah filsafat. Fenomenologi lebih tepatnya ialah pendalaman kesadaran-diri, pencarian yang gelisah ini terhadap sesuatu di balik objek-objek yang di dalamnya kita --biasanya dan secara ilmiah-- mengalahkan perhatian kita, atau seperti yang kita sekarang menyebutnya tujuan.

Fenomenolog hanyalah seseorang yang tidak terkandung dalam objek atau subjek semata, melainkan concern dengan keduanya dalam integritas intensionalnya. Fenomenologi bukan hanya teori bahwa ini adalah begitu, tapi menempatkan dalam prakteknya, dorongan untuk mengeksplorasi pandanganpandangan yang tak berkesudahan. Jika seseorang dapat memperbincangkan filsafat modern sebagai fokus pertama kesadaran-diri manusia, ia dapat berbicara tentang fenomenologi sebagai eksplorasi aktifnya. ${ }^{17}$

Persoalan selanjutnya ialah di manakah kita menangkap realitas? Dalam pengertian kita, di situlah kita bertemu dan bersatu dengan realitas. Dalam pertemuan itu realitas menampakkan diri, menggejala. Akan tetapi, pada saat yang sama, ia juga menyembunyikan diri. Aneh, bukan? Namun bukankah demikian halnya? Pengertian kita tentang suatu hal bisa bertambah, menjadi lebih sempurna: karena kita menyelidiki, bertanya, terus bertanya. Bukankah itu bukti, bahwa realitas itu menggejala dan menampakkan diri bersamaan itu juga menyembunyikan diri dan barulah kemudian lebih membuka diri, jika kita bertanya?

Bertanya kepada fenomenon berarti menghilangkan kabut yang menyelimuti realitas, yang menggejala kepada kita tersebut. Realitas mewahyukan diri, akan tetapi bersama itu juga berkerudung atau bertabir (onthulling verhulling). Dan yang menyebabkan kabut itu tidak hanya realitas yang kita hadapi, melainkan juga diri kita sendiri. Pelbagai konsepsi, cara berpikir, dan

${ }^{17}$ Wild, Contemporary Phenomenology and the Problem of Existence, 169. 
suasana hidup kadang-kadang merupakan kabut tebal --yang tidak hanya dari kita sendiri, melainkan ditanam, dimasukkan ke dalam hati sanubari kita oleh zaman yang kita alami. Demikian pula bagi Husserl dan manusia Eropa pada waktu itu. Alam pikiran, atau aliran-aliran filsafat pada saat itu, menjauhkan manusia dari pengertian yang sebenarnya: realitas. ${ }^{18}$

Edmund Husserl dilahirkan di Prossnitz (Moravia) pada tahun 1859. Pada masa hidupnya dia pernah menjadi guru besar di Halle Gottingen dan Freiburg. Ahli pikir yang sangat giat bekerja itu mengakhiri hidupnya pada 1938. Bersamasama dengan Berson, Husserl adalah tokoh yang besar pengaruhnya dalam alam pikiran dewasa ini. ${ }^{19}$ Dengan merujuk pada karya Husserl Logische Untersuchungen, N. Drijarkara memetakan pemikiran filosofis Husserl menjadi tiga bagian: 1) Fenomenologi sebagai Metode dalam filsafat Husserl, 2) Fenomenologi sebagai Ajaran dalam filsafat Husserl, dan 3) Realisme dan Idealisme dalam ajaran Husserl. ${ }^{20}$

Kerja filsafat Husserl dimulai pada dekade pertama abad ke-20. Dalam ceramah-ceramah yang disampaikan pada 1907, dengan anumerta diterbitkan di bawah judul The Idea of Phenomenology, Husserl memperkenalkan apa yang dia sebut fenomena transendental, sebagai sebuah pendekatan yang diperlukan pertimbangan-pertimbangan epistemologis, yakni, untuk menjawab apa yang dipahaminya sebagai problem pengetahuan. ${ }^{21}$

Problem pengetahuan, atau lebih tepatnya kebenaran ilmu pengetahuan, merupakan persoalan yang secara langsung dibidik Husserl. Ia menyatakan, "Rechtsanspruch auf Gegestandlichkeit": kita mengerti, dan dalam pengertian itu kita berkata bahwa pengertian itu mempunyai objek. Untuk mencari pemecahan soal ini harus dilihat pendirian kita sehari-hari dalam mengalami pengertian. Mungkin di dalamnya terdapat hal-hal yang menggelapkan, mempersukar atau merintangi tercapainya kebenaran. Kita mempunyai pendirian yang biasa dan

\footnotetext{
${ }^{18}$ N. Driyarkara:, Percikan Filsafat, 120.

${ }^{19}$ Ibid., 121.

${ }^{20}$ Ibid., 121-135.

${ }^{21}$ Henry Pietersma, Phenomenological Epistemology (Oxford University Press, 2000), 37.
} 
spontan (naturliche Einstellung). ${ }^{22}$ Dengan kata-kata ini Husserl memulai paparannya tentang pendirian kita sehari-sehari dalam mengalami pengertian hewan-hewan, manusia, barang-barang, dunia dan seterusnya, semua itu kita akui sebagai objektif. Jika kita rumuskan, maka keyakinan kita tersebut dapat dikatakan 'demikian', Die Welt ist als Wirklichkeit immer da.

Pengalaman-pengalaman kesukaran ini melahirkan beragam teori tentang hakikat pengertian dan kebenaran Husserl -bapak Fenomenologi- adalah yakin, bahwa teori-teori yang ada sampai waktu itu tak berhasil menerangkan pengertian. Malahan sebaliknya hanya menimbulkan kabut yang menutupi segala-segalanya. Aliran Psikologisme misalnya, menyatakan bahwa apa yang dikatakan pengertian tak lain ialah kesan-kesan. Positivisme mengajarkan bahwa manusia itu dalam pengertiannya tak bisa melampaui pengalaman. Husserl meyakini, bahwa kesalahan-kesalahan teori itu terletak dalam pendirian yang salah: yakni pendirian yang tidak mengamati kontak kita dengan realitas. Kontak yang pertama dan mendasar itu dalam hidup biasa dikaburkan dengan pelbagai pendirian dan pendapat.

Wacana pemikiran berikutnya dapat dilihat sebagai upaya untuk memenuhi atau menyempurnakan wawasan metodologis sebagai jalan tengah antara publikasi Logical Investigations (1900/01), sebuah klarifikasi dari konsepkonsep dasar logika murni melalui psikologi deskriptif, dan Ideas I (1913), suatu upaya sistematis yang mencoba memperkenalkan fenomenologi transendental sebagai disiplin filsafat yang fundamental. ${ }^{23}$

Maka, menurut Hassan Hanafi, Husserl mengkritik formalisme dan materialisme logika, dan membuat logika kesadaran, yaitu fenomenologi, sebagaimana ia mengkritik formalisme dan materialisme filsafat untuk kemudian meletakkan filsafat kesadaran, yaitu fenomenologi transendentalisme. ${ }^{24}$ Seperti ditunjukkan sendiri oleh Husserl, tujuan fenomenologi transendental bukanlah untuk menjamin objektivitas tetapi memahaminya. ${ }^{25}$

\footnotetext{
${ }^{22}$ N. Driyarkara:, Percikan Filsafat, 122.

${ }^{23}$ Pietersma, Phenomenological Epistemology, 47.

${ }^{24}$ Hasan Hanafi, Islamologi 2: Dari Rasionalisme ke Empirisme, 2004, 249.

${ }^{25}$ Hyder and Rheinberger, Science and the Life-World.
} 
Selanjutnya, Hanafi menemukan hal yang sama pada (pemikiran) Husserl. Fenomenologi menuntut dua hal. Pertama, data kesadaran yang berasal dari celah-celah pengalaman dinamis. Data ini merupakan objek yang dicapai dalam kesadaran. Kedua, analisis rasional terhadap data dan meletakkannya dalam logika kesadaran. Yang pertama adalah noêma, sedangkan yang kedua adalah analisis rasional atas noétic dan noêma. Yang pertama adalah rasio sedangkan yang kedua adalah realitas kesadaran. Husserl telah mampu memformulasikan pengalaman filosofisnya ke dalam ilmu pengetahuan yang rigorus-apodiktif, yaitu "fenomenologi" sebagaimana Suhrawardi yang telah mampu memformulasikan pengalaman spiritualnya ke dalam logika yang rigorus-apodiktif, yaitu "filsafat iluminasi". ${ }^{26}$

Karya Husserl telah diikuti oleh maraknya ragam tulisan fenomenologis pada paruh pertama abad keduapuluh. Encyclopedia of Phenomenology (Dordrecht: Kluwer Academic Publishers, 1997) menyebutkan tujuh tipe fenomenologi:

1. Fenomenologi Konstitutif-Transendental yang mempelajari bagaimana objek-objek yang terbentuk dalam kesadaran murni atau transendental, dengan mengesampingkan persoalan-persoalan setiap relasi dunia natural yang mengitari kita.

2. Fenonemologi Konstitutif-Naturalistik yang mengkaji bagaimana kesadaran membentuk atau mengambil segala sesuatu di dunia natural, dengan mengasumsikan perilaku alami bahwa kesadaran adalah bagian dari alam.

3. Fenomenologi Eksistensial yang membahas eksistensi manusia yang konkrit, meliputi pengalaman kita akan pilihan atau tindakan yang bebas dalam situasi-situasi konkrit.

4. Fenomenologi Historis-Generatif yang mempelajari bagaimana makna, yang ditemukan dalam pengalaman kita, dihasilkan dalam proses historis dari pengalaman kolektif sepanjang waktu.

${ }^{26}$ Hanafi, Islamologi 2, 333. 
5. Fenomenologi Genetik yang mengkaji asal usul makna segala sesuatu dalam arus pengalaman seseorang.

6. Fenomenologi Hermeneutik yang membahas struktur interpretatif pengalaman, bagaimana kita memahami dan mengikat segala sesuatu di sekitar kita dalam dunia kemanusiaan kita, termasuk kita sendiri dan orang lain.

7. Fenomenologi Realistik yang mempelajari struktur kesadaran dan intensionalitas, dengan mengsumsikan bahwa ia terjadi dalam dunia riil yang lebih eksternal terhadap kesadaran. ${ }^{27}$

Tidak ada yang menyangkal pengaruh Husserl terhadap Heidegger, baik secara personal maupun intelektual. ${ }^{28}$ Perhatian utamanya ialah persoalan mengenai wujud. Meskipun bahasa Heidegger lebih kuat ontologis, titik tekan diberikan terhadap fakta bahwa ia melihat ontologi dalam Being and Time (1927) -sebuah karya yang secara khusus didedikasikan kepada Husserl, seperti argumennya, sebuah ontologi dalam bentuk fenomenologi. Ontologi dipahami bukan sebagai ilmu dalam arti sederhana-tradisional, terutama metafisika praKantian.

Ontologi sebagai fenomenologi secara eksplisit merupakan urutan kedua: hal ini ditentukan secara tidak langsung, yaitu sebagai makna wujud. Ontologi hendak menggambarkan pengalaman urutan pertama yang di dalamnya wujud dan kebenaran dipahami dengan cara tertentu. Tugas filsafat yang diterapkan Heidegger dalam Being and Time ialah menguraikan atau mengartikulasikan bahwa makna wujud yang sudah ada dalam pengalaman, sekalipun dalam bentuk distorsi yang buruk. Dengan kata lain, ontologi memandang wujud segala sesuatu dalam hubungan yang intim dengan pengalaman. ${ }^{29}$

Heidegger menuturkan, bahwa manusia tak mungkin memiliki "kesadaran" jika tidak ada "lahan kesadaran", suatu tempat, panorama, dunia, agar "kesadaran" dapat terjadi di dalamnya; sehingga suatu eksistensi bersifat duniawi.

${ }^{27}$ N. Driyarkara:, Percikan Filsafat, 156.

28 William Large, Heidegger's Being and Time: An Edinburgh Philosophical Guide: An Edinburgh Philosophical Guide (Edinburgh University Press, 2008), 4.

${ }^{29}$ Pietersma, Phenomenological Epistemology, 87. 
Atau "ada" dan dunia tak dapat dipisahkan. Konsekuensinya, suatu eksistensi bersifat temporal karena ia selalu terkungkung dimensi waktu. Dan "kesadaran" sendiri tak pernah berinteraksi langsung dengan realitas jika eksistensi tidak menyeruak menembus "kesadaran". Titik kulminasinya, ke-ada-an mempunyai struktur tiga lapis yang berhubungan dengan masa lalu, masa sekarang, dan masa depan. Jelas bahwa Heidegger hendak menyatukan antara fenomenologi dan ontologi (makna "ada"); mempertanyakan fenomena "ada". Dalam arti, bagaimana "ada" menjadi "ada", dan kenapa tidak menjadi "tidak ada"? Satu poin penting, pendekatan Heidegger berbeda dengan Husserl. Di sini Heidegger "meluaskan lingkup" konsep Husserl terkait "keterarahan kesadaran". Pada kenyataannya, Husserl sendiri memang menyangkal bahwa Heidegger merupakan pewaris sah pemikirannya. ${ }^{30}$

Husserl, pada prakteknya, hanya meninggalkan dua kaidah penting dalam fenomenologi: reduksi fenomenologis ${ }^{31}$ dan konstitusi. Reduksi fenomenologis merupakan upaya peralihan pandangan dari alam real menuju "kesadaran". Dalam arti, jika sikap natural terhadap fenomena alam "menerima apa adanya", maka reduksi fenomenologis berarti penangguhan "kepercayaan" terhadap dunia riil. Namun sikap tersebut tidak berarti menafikan realitas, sebab reduksi fenomenologis hanya semacam upaya "netralisasi" --dalam istilah Husserl-- diberi tanda kurung (eingeklammert). Di sini Husserl membedakan antara reduksi fenomenologis dan reduksi eidetik. Perbedaannya adalah, reduksi fenomenologis mengindahkan alam riil untuk sementara, guna menyibak 'esensi'. Sedang reduksi eidetik mementingkan esensi (eidos) tetapi dalam bentuknya yang paripurna. Reduksi fenomenologis ini yang kemudian dinamakan "sikap fenomenologis". Adapun konstitusi merupakan proses tampaknya fenomena terhadap "kesadaran". Konstitusi merupakan fase kedua setelah reduksi fenomenologi; tampaknya fenomena dalam "kesadaran", selanjutnya akan bersatu dengan "kesadaran", dan subjeknya kemudian disebut "pelaku kesadaran". Dengan demikian, fenomenologi berarti mengurai relasi antara subjek dan kesadaran.

${ }^{30}$ Large, Heidegger's Being and Time.

${ }^{31}$ N. Driyarkara:, Percikan Filsafat, 122-123. 
Satu nama lagi -tanpa bermaksud menafikan nama-nama besar lainnya-dalam ranah kajian fenomenologi ialah Maurice Merleau-Ponty. Pada 1940-an, bersama dengan Sartre dan Beauvoir, ia mengembangkan fenomenologi. Dalam Phenomenology of Perception (1945), ia menggagas sebuah varian fenomenologi yang kaya dengan menekankan peran tubuh dalam pengalaman manusia. Tidak seperti Husserl, Heidegger, dan Sartre, Merleau-Ponty mendambakan psikologi eksperimental, dengan menganalisa pengalaman yang dilaporkan orang cacat yang merasakan sensasi-sensasi dalam pohon berhantu. Merleau-Ponty menolak baik psikologi asosiasionis, yang memusatkan pada korelasi-korelasi antara sensasi dan rangsangan, maupun psikologi intelektualis, yang terfokus pada konstruksi dunia rasional dalam akal pikiran. ${ }^{32}$

Lingkup Phenomenology of Perception ialah karakteristik luasnya fenomenologi klasik, sama sekali bukan karena Merleau-Ponty menggambarkan kemurahan hati atas Husserl, Heidegger, dan Sartre ketika menciptakan visi fenomenologinya yang inovatif. Fenomenologinya menunjukkan peran dari atensi dalam medan fenomenal, pengalaman tubuh, tubuh dalam wujud seksual dan dalam kemampuan bicara, kesementaraan, dan karakter kebebasan begitu penting dalam eksistensialisme Perancis.

\section{Metode Penelitian}

Penelitian ini dilakukan dengan menggunakan metode library research yakni mengumpulkan beberapa referensi yang terkait dengan pembahasan penelitian ini. Hal ini dilakukan dengan analisis deksriptif.

\section{Pembahasan}

Adalah suatu kenyataan bahwa fenomenologi banyak memperbincangkan atau memasuki area-area filsafat pikiran (philosophy of mind). Hal ini dikarenakan pelbagai tradisi keduanya berhubungan erat, meskipun dengan bidang-bidang minat yang saling melengkapi. Maka, upaya mendekatkan survei fenomenologi ini

${ }^{32}$ The Team of Stanford, Phenomenology, n.d., 224. 
dengan penyebutan filsafat pikiran, menurut hemat penulis, merupakan langkah yang cukup tepat.

Tradisi filsafat analitis dimulai pada abad duapuluh, dengan analisa-analisa bahasa, terutama dalam karya-karya Gottlob Frege, Bertrand Russell dan Ludwig Wittgenstein. Gilbert Ryle dalam The Concept of Mind (1949) mengembangkan seperangkat analisa bahasa mengenai kondisi mental yang berlainan, meliputi sensasi (sensation), keyakinan (belief), dan keinginan (will). ${ }^{33}$ Setelah Ryle, muncul nama-nama lain seperti Thomas Nagel (1970-an) dan John Searle, yang terkenal dengan dua karya terbaiknya, Intentionality (1983) dan The Rediscovey of the Mind (1991). ${ }^{34}$

Searle berpendapat bahwa intensionalitas dan kesadaran merupakan properti esensiil dari kondisi-kondisi mental. Baginya, otak kita memproduksi kondisi-kondisi mental dengan properti kesadaran dan intensionalitas, dan ini seluruhnya adalah bagian dari biologi kita, sebab kesadaran dan intensionalitas mensyaratkan sebuah ontologi "orang-pertama".

Analisa kesadaran dan intensionalitas adalah pusat bagi fenomenologi sebagaimana telah disebutkan di atas, dan teori intensionalitas Searle terlihat seperti sebuah versi modern dari teori Husserl. Teori logika kontemporer mempergunakan bentuk kondisi-kondisi mempernyatakan kebenaran bagi proposisi-proposisi, dan Searle menggolongkan suatu kondisi intensionalitas mental dengan menetapkan "kondisi-kondisi kepuasaan"nya. ${ }^{35}$

Sejak pertengahan 1990-an sejumlah penulis yang bergelut dalam filsafat pikiran telah memfokuskan pada karakter kesadaran fundamental, yang pada akhirnya menyangkut isu fenomenologis. Apakah kesadaran selalu dan pada dasarnya meliputi kesadaran-diri, atau kesadaran-atas-kesadaran, sebagaimana digambarkan secara mendetail oleh Bretano, Husserl, dan Sartre? Jika demikian, setiap tindakan kesadaran baik yang mencakup atau berdampingan dengan kesadaran-atas-kesadaran-itu. Apakah kesadaran-diri itu mengambil bentuk dalam

\footnotetext{
${ }^{33}$ Ibid., 228.

${ }^{34}$ Beth Lord, Spinoza's Ethics: An Edinburgh Philosophical Guide (Edinburgh University Press, 2010).

${ }^{35}$ The Team of Stanford, Phenomenology, 229.
} 
suatu pemantauan-diri internal? Andaikata demikian, apa itu pemantauan tatanan yang lebih tinggi, di mana setiap tindakan kesadaran dilebur oleh tindakan mental yang lebih jauh memantau tindakan dasar? Ataukah pemantauan terhadap tatanan yang sama sebagai tindakan dasar, sebuah bagian yang tepat dari tindakan yang tanpa tindakan tersebut tidak akan menjadi sadar?

Pembagian kerja dalam teori pikiran (theory of mind) dapat dilihat sebagai perluasan dari pembedaan asli Brentano antara psikologi deskriptif dan genetik. ${ }^{36}$ Fenomenologi menawarkan analisa-analisa deskriptif terhadap fenomena mental, sementara neuroscience (dan biologi yang lebih luas dan akhirnya fisika) menawarkan model-model penjelasan hal-hal yang menyebabkan atau menimbulkan fenomena mental. Teori budaya menawarkan analisa-analisa atas pelbagai aktivitas sosial dan dampaknya terhadap pengalaman, mencakup cara cara bahasa membentuk pikiran, emosi, dan motivasi kita. Dan ontologi membingkai semua hasil ini dalam sebuah skema struktur dunia dasar, termasuk pikiran kita sendiri.

Sementara itu, dari sudut epistemologis, seluruh aspek dari teori tentang pikiran dimulai dengan bagaimana kita mengamati, mempertimbangkan, dan berusaha menjelaskan fenomena yang kita jumpai di dunia. Dan itulah tempat di mana fenomenologi (me)mulai. Selain itu, bagaimana kita memahami setiap bagian dari teori, termasuk teori tentang pikiran, merupakan pusat dari teori intensionalitas, sebagaimana pula, semantik pemikiran dan pengalaman pada umumnya. Dan inilah jantung dari fenomenologi.

\section{Kesimpulan}

Dari uraian dan pemaparan di atas, tampak secara jelas, seperti tiap-tiap aliran filsafat, demikian pula fenomenologi dilahirkan dari keyakinan, bahwa manusia bisa mencapai kebenaran dan dari keharusan untuk memperolehnya. Dasar fenomenologi ialah pengertian prekonseptual kita yang sangat padat. Kekayaannya sebagai metode dalam semua ilmu pengetahuan, berperan aktif dalam rangka menyelidiki kehidupan manusia atau Geisteswissenschaften. Ilmu jiwa, sosiologi, estetika, ilmu-ilmu kebudayaan, semua itu sebenarnya tidak

${ }^{36} \mathrm{Ibid}$. 
mungkin tanpa metode fenomenologi. Juga filsafat, harus menggunakan metode tersebut sebagai propedeutica atau persiapannya.

Fenomenologi meletakkan problematika yang sama, yaitu pada batasan manakah kemungkinan kompromisasi atau akumulasi, antara paradigma persepsi dan paradigma intuisi meminjam bahasa Suhrawardi atau antara orientasi rasional dan orientasi empirik menurut pandangan Husserl. Demikian itu untuk membangun paradigma yang satu, yaitu paradigma kesadaran yang mengakumulasikan rasio dan realitas dalam pengalaman empirik yang dinamis: paradigma fenomenologi.

\section{Daftar Pustaka}

Adi, Rianto. Metodologi penelitian sosial dan hukum. Granit, 2004.

Ameriks, Karl. The Cambridge Companion to German Idealism. Cambridge University Press, 2000.

Arifin, Tajul. Western Philosophy. Bandung: Postgraduate Program The Sunan Gunung Djati State Islamic University, 2012.

Hanafi, Hasan. Islamologi 2: Dari Rasionalisme ke Empirisme, 2004.

Hanafì, Hasan. Tafsir fenomenologi: Bag. 1 / Hasan Hanafi ; penerjemah: Yudian Wahyudi; kata pengantar: Yudian W. Asmin. Pesantren Pasca Sarjana Bismillah Press, 2001.

Hardiman, Francisco Budi. Kritik ideologi: pertautan pengetahuan dan kepentingan. Penerbit Kanisius, 1993.

Husserl, Edmund. The Idea of Phenomenology: A Translation of Die Idee Der Phänomenologie Husserliana II. Springer Science \& Business Media, 2013.

Hyder, David, and Hans-Jörg Rheinberger. Science and the Life-World: Essays on Husserl's Crisis of European Sciences. Stanford University Press, 2009.

Large, William. Heidegger's Being and Time: An Edinburgh Philosophical Guide: An Edinburgh Philosophical Guide. Edinburgh University Press, 2008.

Lord, Beth. Spinoza's Ethics: An Edinburgh Philosophical Guide. Edinburgh University Press, 2010.

Magnis-Suseno, Franz. Menalar Tuhan. Kanisius, 2006.

Munslow, Alun. The Routledge Companion to Historical Studies. Taylor \& Francis, 2006.

N. Driyarkara: Percikan Filsafat, 2013.

Pietersma, Henry. Phenomenological Epistemology. Oxford University Press, 2000.

The Team of Stanford. Phenomenology, n.d.

Wild, John. Contemporary Phenomenology and the Problem of Existence. U of Buffalo/N.V. Erven P. Noordhoff, n.d. 